\title{
A TRACKING SURVEY OF RESOURCE FLOW FROM UBEC TO PUBLIC PRIMARY SCHOOLS IN IBADAN NORTH LOCAL GOVERNMENT AREA OF OYO STATE, NIGERIA
}

\author{
AbisolaA. Gbenro, Joel B. Babalola \\ Department of Educational Management, Faculty of Education, University of Ibadan, Ibadan, Nigeria \\ bisolag@yahoo.com \\ Department of Educational Management, Faculty of Education, University of Ibadan, Ibadan, Nigeria \\ joelbabalola2000@yahoo.co.uk
}

\begin{abstract}
The tracking of public spending on education has gradually become a fashionable practice because of the general view that public expenditure may not reach the publicly run schools due to leakages triggered by corruption, mismanagement and weak monitoring mechanisms. This has increased the fear that the expenditure on primary education might not translate into improved learning. Consequently, this research tracked the flow of instructional materials from the Federal Government Agency through the State Government Agency and the Local Government Agency to the primary school level, assessed the efficiency of public spending and determined the location and scale of anomaly by adopting Public Expenditure Tracking Survey (PETS) to address issues of public accountability in the management of the Universal Basic Education funds in Oyo state. Descriptive survey research design was adopted for the study using the quantitative and qualitative multi-angular data collection strategy which blended primary survey-based data with secondary information from documentary sources. The population of the study consisted of all seventy four (74) primary schools in Ibadan North Local Government area of Oyo State, Nigeria. The results indicated a significant evidence of resource leakage, existence of lobbying, hoarding of textbooks by some schools and lack of information to the stakeholders on funds released and allocation to schools. Based on the findings, the study recommended that necessary information on public allocations be made readily available to all stakeholders and that policy reforms be made to improve and enforce public accountability in the process of basic education delivery especially in Oyo State, Nigeria.
\end{abstract}

\section{Indexing terms/Keywords}

Public Spending, Public Expenditure,Instructional Materials, Public Expenditure Tracking Survey, Public Accountability.

\section{Academic Discipline And Sub-Disciplines}

Education; Economics of Education

\section{SUBJECT CLASSIFICATION}

Education

\section{TYPE (METHOD/APPROACH)}

Literary Analysis and original research; Survey/Interview

\section{Council for Innovative Research}

Peer Review Research Publishing System

\section{Journal: International Journal of Research in Education methodology}

Vol. 7, No.1

ijremeditor@gmail.com

www.ijrem.com 


\section{INTRODUCTION}

Education is one of the most powerful instruments for reducing poverty and inequality and lays a foundation for sustained economic growth. Expenditure on education is an investment that boosts productivity, facilitates economic growth, reduces inequality among social groups and contributes to the personal and social development of individuals. Education is a sector of the economy where all governments intervene to promote access to educational opportunities. Despite privatization in the sector, education is still a social service and it is one of the indicators for human development.

Article 26 of the 1948 Universal Declaration of Human Rights states that, "everyone has the right to education." It unlocks doors and increases opportunities and freedoms. It contributes to nurturing peace, democracy and economic growth as well as improving health and reducing poverty. The ultimate aim of Education for All (EFA) is sustainable development and goal two (2) of the EFA Goals is to to provide free and compulsory primary education for all. Goal two (2) of the complimentary Millennium Development Goals (MDGs) is to achieve universal primary education by 2015 and the target is to ensure children everywhere, boys and girls alike, will be able to complete a full course of basic schooling.

The Universal Basic Education (UBE) programme is Nigeria's strategy for the achievement of EFA and the educationrelated MDGs. UBE was launched in Nigeria on 30th September, 1999. The programme is intended to be universal, free, and compulsory. Since the introduction of western education in 1842 (Eya, 2000), regions, states, and federal governments in Nigeria have shown a keen interest in education. This can be seen in the introduction of the Universal Primary Education (UPE) in the western region on 17th January, 1955, its introduction in the eastern region in February, 1957, and in Lagos (then Federal Territory) in January, 1957. Other developments include the publication of a National Policy on Education in 1977, launching Universal Free Primary Education on 6th September, 1976, and the subsequent launch of UBE in 1999. The goal of all these programmes is providing functional, quality and free Universal Basic Education for every Nigerian child of school going age irrespective of age, sex, race, religion, occupation, or location. By 2014, Compulsory, Free Universal Basic Education Act, 2004 (CFUBEA 2004) makes provision for basic education comprising of ECCE, Primary and Junior Secondary Education. The financing of basic education is the responsibility of States and Local Governments. However, the Federal Government has decided to intervene in the provision of basic education with $2 \%$ of its Consolidated Revenue Fund. The Act also provides for the establishment of the Universal Basic Education Commission (UBEC) to co-ordinate the implementation of the programme at the states and local governments through the State Universal Basic Education Board (SUBEB) of each state and the Local Government Universal Basic Education Authorities (LGUBEAs). UBEC was formally established on 7th October 2004.

The need for evaluation of public spending arise because public expenditure may not reach the frontline service providers (publicly run schools) who are often plagued by inadequate infrastructure and teacher absenteeism. These problems lead to lower quality for those who cannot afford private schools and this means that the right to education has been hampered, This research aims to cover the education sector by tracking the flow of public funds and other resources through various levels of government and administrative strata to the primary schools in Ibadan North Local Government of Oyo State by using PETS as a diagnostic tool to understand specific situations and identify specific problems.

\section{REVIEW OF LITERATURE}

This study was based on the Public Accountability Framework(Figure 1)introduced by the World Bank in the 2004 World Development Report, which could be used for public expenditure tracking and service delivery. The study observed the progression of accessing, distributing, utilizing and monitoring the UBE intervention funds released by the federal government with the aim of identifying ways for ensuring public accountability.

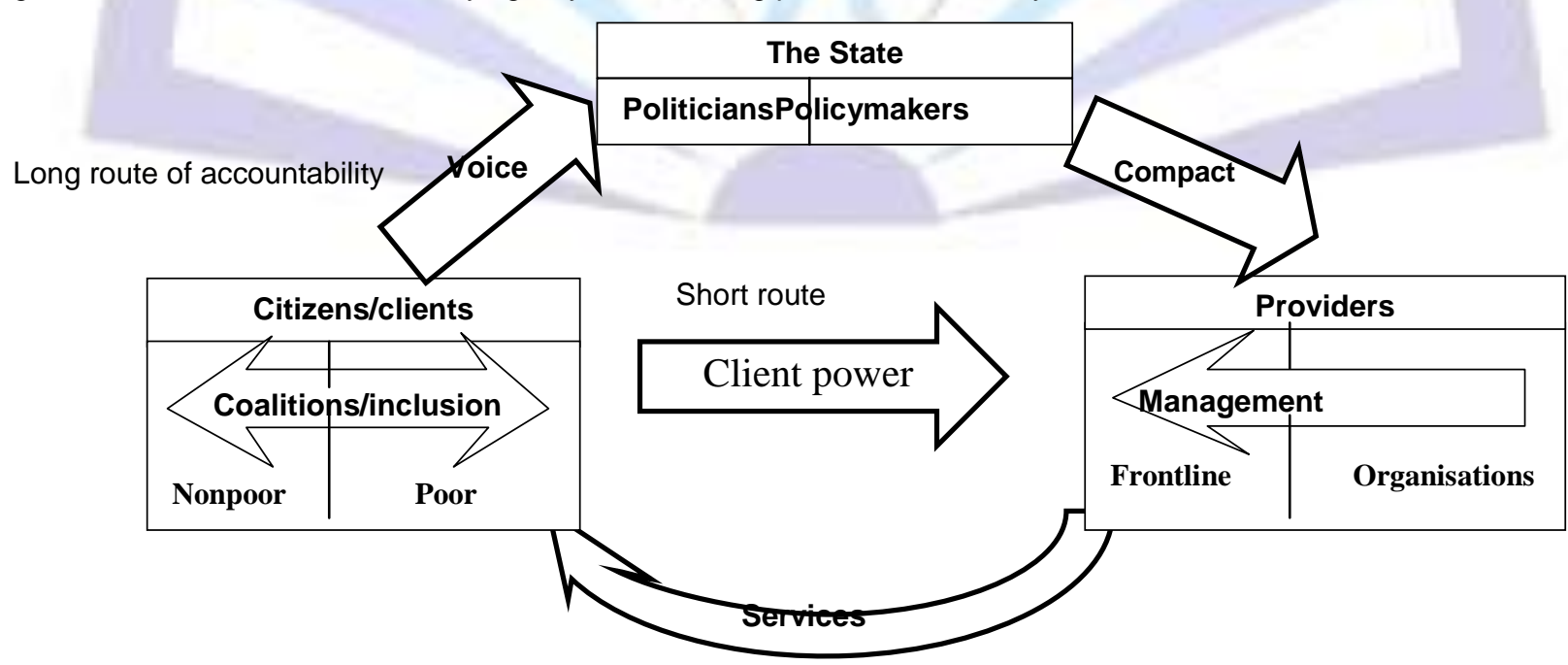

Figure 1 Short and long routes of accountability

Source: World Bank (2004) 
Figure 1 shows the relationship that exists between the four main actors in the education sector: citizens/clients, politicians/policymakers, provider organisations and frontline providers. The study also considered accountability as a relationship among the actors with the features of delegation, finance, performance, information about performance and enforceability (World Development Report, 2004). Bureaucratic approaches of service provision have had many failures as a result of the capture of funds along the bureaucratic ladder (Reinikka\&Svensson, 2004a). According to Reinikka and Smith (2004), this failure has attracted a lot of research and in 1996, PETS conducted in Uganda revealed that "little of the money allocated at the centre reached the schools." It was ascertained that only an average of 13 per cent of the total non-wage spending reached the schools in 1991 to 1995. Many analytical frameworks such as participatory budgets, service scorecards, demand-side transfers, facility surveys have been attempted to show the link between public education spending and outcomes but none of these is a universal remedy.

Under the review of theoretical literature, two types of accountability surveys were reviewed. These are Public Expenditure Tracking Survey (PETS) and Quantitative Service Delivery Survey (QSDS). PETSare quantitative exercises that trace the flow of resources from origin to destination and determine the location and scale of anomaly.QSDS seeks to collect information on service providers and on various agents in the system in order to examine the efficiency of service delivery on the frontline as well as wasteful use of resources. Both surveys have been designed to highlight not only the use and abuse of public money, but also give insights into the concepts of capture and corruption, cost efficiency, decentralization, and accountability. In addition, they recommend solutions to correct these deficiencies.

\subsection{Flow of UBE Intervention Funds in Oyo State}

The flow of UBE intervention funds in Oyo State is shown in figure 2.

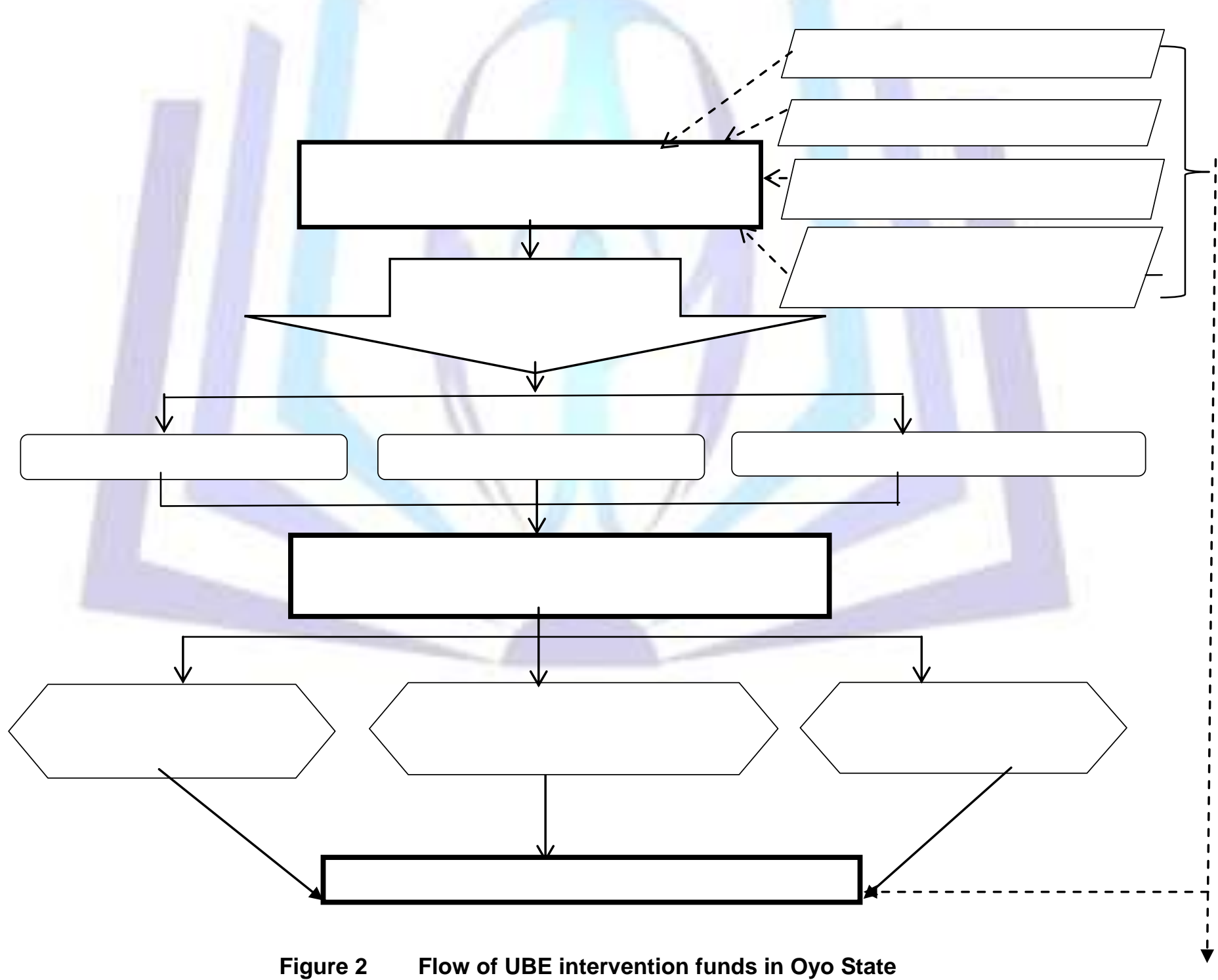

Source: Gbenro, 2014 


\subsection{Levels of Capture and Leakages of Resources}

Major findings that have emerged from PETS and QSDS carried out in Africa, Asia and Latin America are summarized below.

Table 1 Evidence of captures and leakage of non-wage funds in primary education

\begin{tabular}{|c|c|c|}
\hline Country & Year & Capture (\%) \\
\hline Uganda & 1996 & 87 \\
\hline Tanzania & 1998 & 57 \\
\hline Ghana & 1998 & 49 \\
\hline Peru & 2001 & 30 \\
\hline Zambia & 2001 & 76 \\
\hline
\end{tabular}

Sources: Ye and Canagarajah, 2002 for Ghana;InstitutoApoyo and World Bank, 2002 for Peru; Price Waterhouse Coopers, 1999 for Tanzania; Reinikka and Svensson, 2001 for Uganda; Das, Dercon, Habyarimana and Krishnan, 2004 for Zambia.

\subsubsection{Fund Utilisation in Nigeria}

The process of fund utilisation in Nigeria begins with the Federal Government who releases funds to UBEC who in turn, disburses the funds to SUBEB in accordance with stipulated guidelines and monitoring mechanisms (Babalola, Tukur and Nzeribe ,2007).In each of the various branches or resource flows of the allocation procedure in Nigeria, there are possibilities of leakage in the processes for fund utilisation (see figure 3).

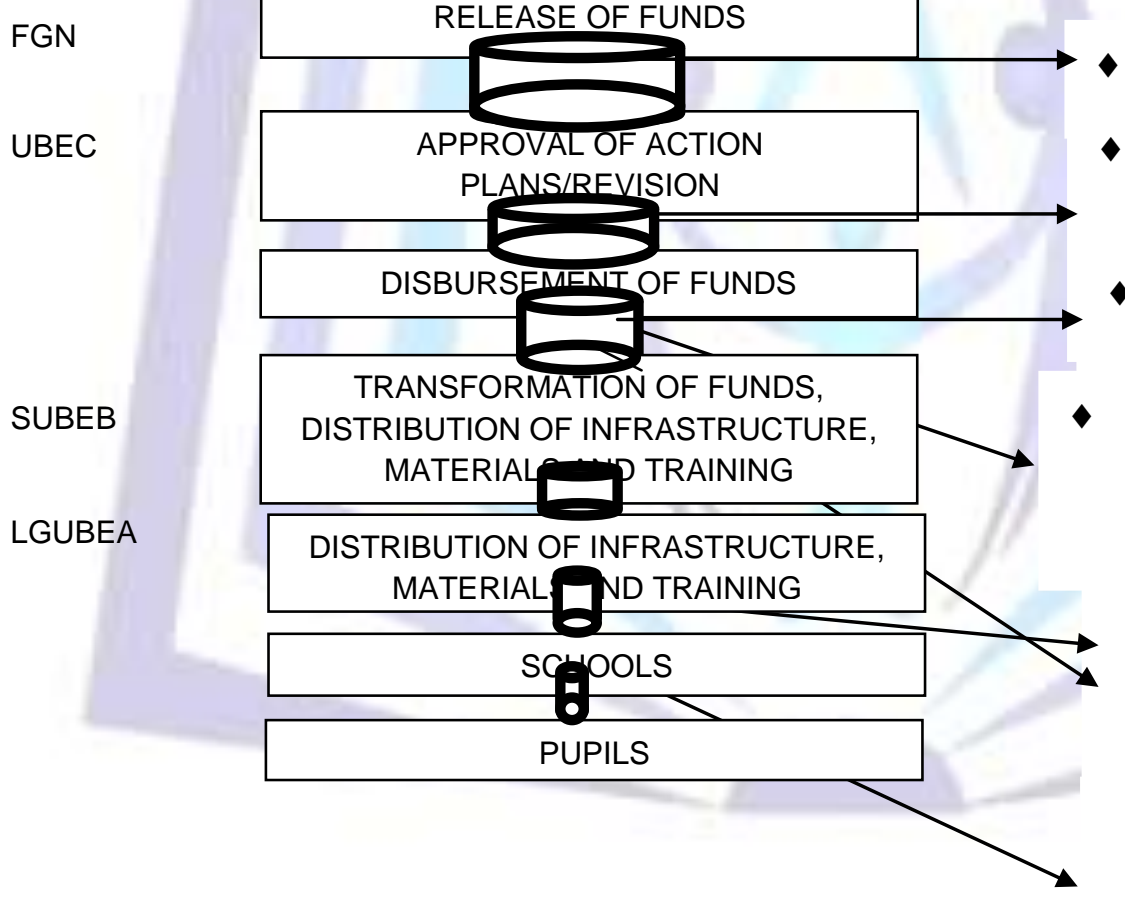

\section{Delay in release of funds as and} when dı

Delays at UBEC-

$\Rightarrow$ Processing of Action Plans

$\Rightarrow$ Release of funds

\section{Delays at SUBEB}

$\Rightarrow$ Action Plan inadequacies

Leakages

$\Rightarrow$ Over-costing

$\Rightarrow$ Virement

$\Rightarrow$ Undue processes, etc.

$$
\begin{aligned}
& \Rightarrow \text { Ineffective training } \\
& \Rightarrow \text { inequalities of distribution } \\
& \Rightarrow \text { diversions } \\
& \Rightarrow \text { failure to execute projects } \\
& \Rightarrow \quad \text { Distribution } \\
& \Rightarrow \quad \text { Damage } \\
& \Rightarrow \quad \text { Sales }
\end{aligned}
$$

Figure 2 Processes for funds utilisation

Source: Babalola, Tukur and Nzeribe, 2007

\section{RESEARCH QUESTION}

In the light of the information presented, the following question arises: how much of the ECCDE and primary school instructional materials supplied by SUBEB end up at the school level?

\section{METHOD}

The population of the study consists of all seventy four (74) primary schools in Ibadan North Local Government of Oyo State, Nigeria. Out of this 74, only 69 were responsive. Ibadan North Local Government is one of the 33 local governments of the State and it comprises of the high density areas. 
Descriptive Survey Research Design was adopted for the study using the Quantitative and Qualitative research approach.The instruments used for data collection are questionnaire (Public Basic Education Expenditure Tracking Survey Questionnaire (PBEETSQ), interview and secondary data obtained from schools' records and the Action Plan of Oyo State Universal Basic Education Board for the year 2007. At the frontline service provider level, the Head Teacher Questionnaire seeks to collect a large spectrum of data and information on schools' characteristics and activities. At the frontline service provider level, the Head Teacher Questionnaire seeks to collect a large spectrum of data and information on schools characteristics and activities.

Both descriptive and inferential statistics were used in analysing the data. This was done with the aid of tables and percentages.

\section{RESULTS}

This section focused on the presentation and analysis of the data obtained from the administered PBEETSQ based on the formulated research questions. The data collected from UBEC, SUBEB and the schools were presented with the aid of tables and percentages in order to track the flow of funds and instructional materials through the hierarchy, from the UBEC to the state and to the schools.

Table 5.1Difference between the number of ECCDE nursery reading and writing textbookssupplied to and received at the school level

\begin{tabular}{|l|c|c|c|}
\hline \multicolumn{1}{|c|}{ Sampled Schools } & $\begin{array}{c}\text { Number supplied } \\
\text { by SUBEB }\end{array}$ & $\begin{array}{c}\text { Number received at } \\
\text { the school level }\end{array}$ & $\begin{array}{c}\text { Proportion of materials supplied } \\
\text { that did not reach the school (\%) }\end{array}$ \\
\hline Methodist, Agodi & 40 & 0 & 100.0 \\
\hline IMG I \& II, Ojelgosun & 43 & 0 & 100.0 \\
\hline Salvation Army I \& II, Kube & 40 & 0 & 100.0 \\
\hline Olive I \& II, Bodija & 52 & 0 & 100.0 \\
\hline St. Peters I \& II, Oke-Are & 30 & 0 & 100.0 \\
\hline CAC I \& II, Oniyanrin & 46 & 0 & 100.0 \\
\hline Total & 251 & 0 & 100.0 \\
\hline
\end{tabular}

Source: Oyo State Universal Basic Education Board, PBEETSQ

Table 5.1 showed that $100 \%$ of the ECCDE reading and writing textbooks supplied by SUBEB did not reach the schools. This showed that none of the 251 textbooks were received by the schools.

Table 5.2Difference between the number of ECCDE nursery mathematics textbooks supplied to and received at the school level

\begin{tabular}{|l|c|c|c|}
\hline \multicolumn{1}{|c|}{ Sampled Schools } & $\begin{array}{c}\text { Number supplied } \\
\text { by SUBEB }\end{array}$ & $\begin{array}{c}\text { Number received at } \\
\text { the school level }\end{array}$ & $\begin{array}{c}\text { Proportion of materials } \\
\text { supplied that did not reach } \\
\text { the school (\%) }\end{array}$ \\
\hline Methodist, Agodi & 40 & 0 & 100 \\
\hline IMG I \& II, Ojelgosun & 43 & 0 & 100 \\
\hline Salvation Army I \& II, Kube & 40 & 0 & 100 \\
\hline Olive I \& II, Bodija & 52 & 0 & 100 \\
\hline St. Peters I \& II, Oke-Are & 30 & 0 & 100 \\
\hline CAC I \& II, Oniyanrin & 46 & 0 & 100 \\
\hline Total & 251 & 0 & 100 \\
\hline
\end{tabular}

Source: Oyo State Universal Basic Education Board, PBEETSQ

The result from Table 5.2 revealed that $100 \%$ of the ECCDE mathematics textbooks supplied to the schools did not reach them. That is, none of the 251 textbooks were received by the schools. 
Table 5.3 Difference between the number of ECCDE nursery living habits textbooks supplied to and received at the school level

\begin{tabular}{|l|c|c|c|}
\hline \multicolumn{1}{|c|}{ Sampled Schools } & $\begin{array}{c}\text { Number supplied } \\
\text { by SUBEB }\end{array}$ & $\begin{array}{c}\text { Number received at } \\
\text { the school level }\end{array}$ & $\begin{array}{c}\text { Proportion of materials supplied } \\
\text { that did not reach the school (\%) }\end{array}$ \\
\hline Methodist, Agodi & 40 & 0 & 100 \\
\hline IMG I \& II, Ojelgosun & 43 & 0 & 100 \\
\hline Salvation Army I \& II, & 40 & 0 & 100 \\
\hline Olive I \& II, Bodija & 52 & 0 & 100 \\
\hline St. Peters I \& II, Oke-Are & 30 & 0 & 100 \\
\hline CAC I \& II, Oniyanrin & 46 & 0 & 100 \\
\hline Total & 251 & 0 & 100 \\
\hline
\end{tabular}

Source: Oyo State Universal Basic Education Board, PBEETSQ

The result from Table 5.3 showed that $100 \%$ of the ECCDE nursery living habits textbooks supplied to the schools listed above did not reach them. This showed that none of the 251 textbooks were received by the schools.

Table 5.4 Difference between the number of ECCDE nursery physical education textbooks supplied to and received at the school level

\begin{tabular}{|l|c|c|c|}
\hline \multicolumn{1}{|c|}{ Sampled Schools } & $\begin{array}{c}\text { Number } \\
\text { supplied by } \\
\text { Olinen }\end{array}$ & $\begin{array}{c}\text { Number received at } \\
\text { the school level }\end{array}$ & $\begin{array}{c}\text { Proportion of materials supplied } \\
\text { that did not reach the school (\%) }\end{array}$ \\
\hline Olive Sch. I, Bodija & 25 & 0 & 100 \\
\hline St. Thomas, Agbowo & 25 & 0 & 100 \\
\hline IMG II, Inalende & 25 & 0 & 100 \\
\hline Methodist I, Bodija & 25 & 0 & 100 \\
\hline St. Paul Sch. III, Yemetu & 25 & 0 & 100 \\
\hline CAC, Oniyanrin & 25 & 0 & 100 \\
\hline St. Mary's, Oke Are & 25 & 0 & 100 \\
\hline Olive Sch. II, Bodija & 33 & 0 & 100 \\
\hline Community Pry, ljokodo & 33 & 0 & 100 \\
\hline Islamic Mission II, Odoye & 33 & 0 & 100 \\
\hline IMG II, Ojelgosun & 33 & 0 & 100 \\
\hline St. John's, Nalende & 33 & 0 & 100 \\
\hline CAC I, Sango & 33 & 0 & 100 \\
\hline Alaafia Institute, Mokola & 33 & 0 & 100 \\
\hline Salvation Army III, & 33 & 0 & 100 \\
\hline Ebenezer, Nalende & 33 & 0 & 100 \\
\hline Islamic Mission III, Odoye & 33 & 0 & 100 \\
\hline Total & 505 & 0 & 10 \\
\hline
\end{tabular}

Source: Oyo State Universal Basic Education Board, PBEETSQ

From Table 5.4 given above, $100 \%$ of the ECCDE nursery physical education textbooks supplied did not reach the schools. That is, none of the 505 textbooks were received by the schools.

Table 5.5 Difference between the number of ECCDE variety toys supplied to and received at the school level

\begin{tabular}{|l|c|c|c|}
\hline \multicolumn{1}{|c|}{ Sampled Schools } & $\begin{array}{c}\text { Number supplied } \\
\text { by SUBEB }\end{array}$ & $\begin{array}{c}\text { Number received at } \\
\text { the school level }\end{array}$ & $\begin{array}{c}\text { Proportion of materials supplied } \\
\text { that did not reach the school (\%) }\end{array}$ \\
\hline Olive Sch. I, Bodija & 13 & 0 & 100 \\
\hline St. Thomas, Agbowo & 13 & 0 & 100 \\
\hline IMG II, Inalende & 13 & 0 & 100 \\
\hline Methodist I, Bodija & 13 & 0 & 100 \\
\hline St. Paul Sch. III, Yemetu & 13 & 0 & 100 \\
\hline CAC, Oniyanrin & 13 & 0 & 100 \\
\hline St. Mary's, Oke Are & 13 & 0 & 100 \\
\hline Olive Sch. II, Bodija & 18 & 0 & 100 \\
\hline Community Pry, ljokodo & 18 & 0 & 100 \\
\hline Islamic Mission II, Odoye & 18 & 0 & \\
\hline
\end{tabular}




\begin{tabular}{|l|c|c|c|}
\hline IMG II, Ojelgosun & 18 & 0 & 100 \\
\hline St. John's, Nalende & 18 & 0 & 100 \\
\hline CAC I, Sango & 18 & 0 & 100 \\
\hline Alaafia Institute, Mokola & 18 & 0 & 100 \\
\hline Salvation Army III, & 18 & 0 & 100 \\
\hline Ebenezer, Nalende & 18 & 0 & 100 \\
\hline Islamic Mission III, Odoye & 18 & 0 & 100 \\
\hline Total & 271 & 0 & \multirow{2}{*}{0} \\
\hline
\end{tabular}

Source: Oyo State Universal Basic Education Board, PBEETSQ

Table 5.5 revealed that, out of 271 ECCDE variety toys supplied, none reached the schools. This showed that $100 \%$ of the variety toys did not reach the schools.

Table 5.6 Difference between the number of Primary English textbooks supplied to and received at the school level

\begin{tabular}{|l|c|c|c|c|}
\hline \multicolumn{1}{|c|}{ Sampled Schools } & $\begin{array}{c}\text { Number supplied } \\
\text { by SUBEB }\end{array}$ & $\begin{array}{c}\text { Number received at the } \\
\text { school level }\end{array}$ & $\begin{array}{c}\text { Proportion of materials } \\
\text { supplied that did not } \\
\text { reach the school }\end{array}$ & $\%$ \\
\hline Methodist, Agodi & 100 & 0 & 100 & 100.0 \\
\hline IMG I \& II, Ojelgosun & 286 & 0 & 100 & 100.0 \\
\hline Salvation Army I \& II, Kube & 130 & 0 & 100 & 100.0 \\
\hline Olive I \& II, Bodija & 300 & 0 & 100 & 100.0 \\
\hline St. Peters I \& II, Oke-Are & 120 & 0 & 100 & 100.0 \\
\hline CAC I \& II, Oniyanrin & 265 & 287 & -22 & -8.3 \\
\hline St. Thomas, Agbowo & 60 & 341 & -281 & -468.3 \\
\hline IMG II, Inalende & 60 & 106 & -46 & -76.7 \\
\hline Methodist I, Bodija & 60 & 0 & 100 & 100.0 \\
\hline St. Paul Sch. III, Yemetu & 60 & 0 & 100 & 100.0 \\
\hline St. Mary's, Oke Are & 60 & 0 & 100 & 100.0 \\
\hline Community Pry, ljokodo & 80 & 200 & -120 & -150.0 \\
\hline Islamic Mission I \&111, & 160 & 589 & -429 & -268.1 \\
\hline St. John's, Nalende & 80 & 0 & 100 & 100.0 \\
\hline CAC I, Sango & 80 & 0 & 100 & 100.0 \\
\hline Alaafia Institute, Mokola & 80 & 89 & -9 & -11.3 \\
\hline Salvation Army III, Yemetu & 80 & 0 & 100 & 100.0 \\
\hline Ebenezer, Nalende & 80 & 0 & 100 & 100.0 \\
\hline Total & 2141 & 1612 & 529 & \\
\hline
\end{tabular}

Source: Oyo State Universal Basic Education Board, PBEETSQ

From Table 5.6 given above, $67 \%$ of the 24 schools received nothing, $33 \%$ received more than they were supposed to get.

Table 5.7 Difference between the number of mathematics textbooks supplied to and received at the school level

\begin{tabular}{|l|c|c|c|c|}
\hline \multicolumn{1}{|c|}{ Sampled Schools } & $\begin{array}{c}\text { Number } \\
\text { supplied by } \\
\text { SUBEB }\end{array}$ & $\begin{array}{c}\text { Number received at the } \\
\text { school level }\end{array}$ & $\begin{array}{c}\text { Proportion of materials } \\
\text { supplied that did not } \\
\text { reach the school }\end{array}$ & $\%$ \\
\hline Methodist, Agodi & 100 & 0 & 100 & 100.0 \\
\hline IMG I \& II, Ojelgosun & 286 & 0 & 286 & 100.0 \\
\hline Salvation Army I \& II, Kube & 130 & 0 & 130 & 100.0 \\
\hline Olive I \& II, Bodija & 300 & 0 & 300 & 100.0 \\
\hline St. Peters I \& II, Oke-Are & 120 & 0 & 120 & 100.0 \\
\hline CAC I \& II, Oniyanrin & 265 & 465 & -200 & -8.3 \\
\hline St. Thomas, Agbowo & 60 & 0 & 60 & -468.3 \\
\hline IMG II, Inalende & 60 & 106 & -46 & -76.7 \\
\hline Methodist I, Bodija & 60 & 0 & 60 & 100.0 \\
\hline St. Paul Sch. III, Yemetu & 60 & 323 & -263 & 100.0 \\
\hline St. Mary's, Oke Are & 60 & 0 & 60 & 100.0 \\
\hline Community Pry, ljokodo & 80 & 632 & -552 & -150.0 \\
\hline Islamic Mission I \& III, Odoye & 160 & 553 & -393 & -268.1 \\
\hline
\end{tabular}


ISSN 2278-7690

\begin{tabular}{|l|c|c|c|c|}
\hline St. John's, Nalende & 80 & 0 & 80 & 100.0 \\
\hline CAC I, Sango & 80 & 0 & -454 & 100.0 \\
\hline Alaafia Institute, Mokola & 80 & 89 & -9 & -11.3 \\
\hline Salvation Army III, Yemetu & 80 & 0 & 80 & 100.0 \\
\hline Ebenezer, Nalende & 80 & 0 & 80 & 100.0 \\
\hline Total & 2141 & 2168 & -27 & \\
\hline
\end{tabular}

Source: Oyo State Universal Basic Education Board, PBEETSQ

Table 5.7 showed that $67 \%$ of the 24 schools received nothing while $33 \%$ received more than they were supposed to get.

Table 5.8 Difference between the number of elementary science textbooks supplied to and received at the school level

\begin{tabular}{|l|c|c|c|}
\hline \multicolumn{1}{|c|}{ Sampled Schools } & $\begin{array}{c}\text { Number supplied by } \\
\text { SUBEB }\end{array}$ & $\begin{array}{c}\text { Number received at } \\
\text { the school level }\end{array}$ & $\begin{array}{c}\text { Proportion of materials } \\
\text { supplied that did not reach the } \\
\text { school (\%) }\end{array}$ \\
\hline Methodist, Agodi & 100 & 0 & 100 \\
\hline IMG I \& II, Ojelgosun & 286 & 0 & 100 \\
\hline Salvation Army I \& II, Kube & 130 & 0 & 100 \\
\hline Olive I \& II, Bodija & 160 & 0 & 100 \\
\hline St. Peters I \& II, Oke-Are & 120 & 0 & 100 \\
\hline CAC I \& II, Oniyanrin & 265 & 0 & 100 \\
\hline Olive Sch. I, Bodija & 60 & 0 & 100 \\
\hline St. Thomas, Agbowo & 60 & 0 & 100 \\
\hline IMG II, Inalende & 60 & 0 & 100 \\
\hline Methodist I, Bodija & 60 & 0 & 100 \\
\hline St. Paul Sch. III, Yemetu & 60 & 0 & 100 \\
\hline St. Mary's, Oke Are & 60 & 0 & 100 \\
\hline Olive Sch. II, Bodija & 80 & 0 & 100 \\
\hline Community Pry, ljokodo & 80 & 0 & 100 \\
\hline Islamic Mission I \& III, Odoye & 160 & 0 & 100 \\
\hline St. John's, Nalende & 80 & 0 & 100 \\
\hline CAC I, Sango & 80 & 0 & 100 \\
\hline Alaafia Institute, Mokola & 80 & 0 & 100 \\
\hline Salvation Army III, Yemetu & 80 & 0 & 100 \\
\hline Ebenezer, Nalende & 80 & 0 & \\
\hline Total & 2141 & 0 & \\
\hline
\end{tabular}

Source: Oyo State Universal Basic Education Board, PBEETSQ

The result from Table 5.8 showed that $100 \%$ of the elementary science textbooks supplied did not reach the schools. I.e. none of the 2141 textbooks were received by the schools.

Table 5.9 Difference between the number of social studies textbooks supplied to and received at the school level

\begin{tabular}{|l|c|c|c|}
\hline \multicolumn{1}{|c|}{ Sampled Schools } & $\begin{array}{c}\text { Number supplied by } \\
\text { SUBEB }\end{array}$ & $\begin{array}{c}\text { Number received at } \\
\text { the school level }\end{array}$ & $\begin{array}{c}\text { Proportion of materials } \\
\text { supplied that did not reach the } \\
\text { school (\%) }\end{array}$ \\
\hline Methodist, Agodi & 100 & 0 & 100 \\
\hline IMG I \& II, Ojelgosun & 286 & 0 & 100 \\
\hline Salvation Army I \& II, Kube & 130 & 0 & 100 \\
\hline Olive I \& II, Bodija & 160 & 0 & 100 \\
\hline St. Peters I \& II, Oke-Are & 120 & 0 & 100 \\
\hline CAC I \& II, Oniyanrin & 265 & 0 & 100 \\
\hline Olive Sch. I, Bodija & 60 & 0 & 100 \\
\hline St. Thomas, Agbowo & 60 & 0 & 100 \\
\hline IMG II, Inalende & 60 & 0 & 100 \\
\hline Methodist I, Bodija & 60 & 0 & 100 \\
\hline St. Paul Sch. III, Yemetu & 60 & 0 & 100 \\
\hline St. Mary's, Oke Are & 60 & 0 & 100 \\
\hline Olive Sch. II, Bodija & 80 & 0 & 100 \\
\hline Community Pry, ljokodo & 80 & 0 & 100 \\
\hline Islamic Mission I \& III, & 160 & 0 & 100 \\
\hline St. John's, Nalende & 80 & 0 & 100 \\
\hline CAC I, Sango & 80 & 0 & 100 \\
\hline Alaafia Institute, Mokola & 80 & 0 & 100 \\
\hline Salvation Army III, Yemetu & 80 & 0 & 100 \\
\hline Ebenezer, Nalende & 80 & 0 & 100 \\
\hline Total & 2141 & 0 & 100 \\
\hline
\end{tabular}

Source: Oyo State Universal Basic Education Board, PBEETSQ 
Table 5.9 showed that $100 \%$ of the social studies textbooks supplied by SUBEB did not reach the schools. This showed that none of the 2141 textbooks were received by the schools.

Table 5.10Difference between the number of basic science and technology textbooks supplied to and received at the school level

\begin{tabular}{|l|c|c|c|}
\hline \multicolumn{1}{|c|}{ Sampled Schools } & $\begin{array}{c}\text { Number supplied by } \\
\text { SUBEB }\end{array}$ & $\begin{array}{c}\text { Number received at } \\
\text { the school level }\end{array}$ & $\begin{array}{c}\text { Proportion of materials } \\
\text { supplied that did not reach the } \\
\text { school (\%) }\end{array}$ \\
\hline Methodist, Agodi & 100 & 0 & 100 \\
\hline IMG I \& II, Ojelgosun & 286 & 0 & 100 \\
\hline Salvation Army I \& II, Kube & 130 & 0 & 100 \\
\hline Olive I \& II, Bodija & 160 & 0 & 100 \\
\hline St. Peters I \& II, Oke-Are & 120 & 0 & 100 \\
\hline CAC I \& II, Oniyanrin & 265 & 0 & 100 \\
\hline Olive Sch. I, Bodija & 60 & 0 & 100 \\
\hline St. Thomas, Agbowo & 60 & 0 & 100 \\
\hline IMG II, Inalende & 60 & 0 & 100 \\
\hline Methodist I, Bodija & 60 & 0 & 100 \\
\hline St. Paul Sch. III, Yemetu & 60 & 0 & 100 \\
\hline St. Mary's, Oke Are & 60 & 0 & 100 \\
\hline Olive Sch. II, Bodija & 80 & 0 & 100 \\
\hline Community Pry, ljokodo & 80 & 0 & 100 \\
\hline Islamic Mission I \& III, Odoye & 160 & 0 & 100 \\
\hline St. John's, Nalende & 80 & 0 & 100 \\
\hline CAC I, Sango & 80 & 0 & 100 \\
\hline Alaafia Institute, Mokola & 80 & 0 & 100 \\
\hline Salvation Army III, Yemetu & 80 & 0 & 100 \\
\hline Ebenezer, Nalende & 80 & 0 & 100 \\
\hline Total & 2141 & 0 & \\
\hline
\end{tabular}

Source: Oyo State Universal Basic Education Board, PBEETSQ

From Table 5.10 given above, $100 \%$ of the basic science and technology textbooks supplied did not reach the schools. That is, none of the 2141 textbooks were received by the schools.

Table 5.11 Difference between the number of computer textbooks supplied to and received at the school level

\begin{tabular}{|l|c|c|c|}
\hline \multicolumn{1}{|c|}{ Sampled Schools } & $\begin{array}{c}\text { Number supplied by } \\
\text { SUBEB }\end{array}$ & $\begin{array}{c}\text { Number received at } \\
\text { the school level }\end{array}$ & $\begin{array}{c}\text { Proportion of materials } \\
\text { supplied that did not reach the } \\
\text { school (\%) }\end{array}$ \\
\hline Olive Sch. I, Bodija & 35 & 0 & 100 \\
\hline St. Thomas, Agbowo & 35 & 0 & 100 \\
\hline IMG II, Inalende & 35 & 0 & 100 \\
\hline Methodist I, Bodija & 35 & 0 & 100 \\
\hline St. Paul Sch. III, Yemetu & 35 & 0 & 100 \\
\hline CAC, Oniyanrin & 35 & 0 & 100 \\
\hline St. Mary's, Oke Are & 35 & 0 & 100 \\
\hline Olive Sch. II, Bodija & 80 & 0 & 100 \\
\hline Community Pry, Ijokodo & 80 & 0 & 100 \\
\hline Islamic Mission I \& III, Odoye & 160 & 0 & 100 \\
\hline IMG II, Ojelgosun & 80 & 0 & 100 \\
\hline St. John's, Nalende & 80 & 0 & 100 \\
\hline CAC I, Sango & 80 & 0 & 100 \\
\hline Alaafia Institute, Mokola & 80 & 0 & 100 \\
\hline Salvation Army III, Yemetu & 80 & 0 & 100 \\
\hline Ebenezer, Nalende & 80 & 0 & 100 \\
\hline Total & 1045 & 0 & 0 \\
\hline
\end{tabular}

Source: Oyo State Universal Basic Education Board, PBEETSQ

The result from Table 5.11 showed that $100 \%$ of the computer textbooks supplied to the schools listed above did not reach them. This showed that none of the 1045 textbooks were received by the schools. 
Table 5.12 Difference between the number of health education textbooks supplied to and received at the school level

\begin{tabular}{|l|c|c|c|}
\hline \multicolumn{1}{|c|}{ Sampled Schools } & $\begin{array}{c}\text { Number supplied by } \\
\text { SUBEB }\end{array}$ & $\begin{array}{c}\text { Number received at } \\
\text { the school level }\end{array}$ & $\begin{array}{c}\text { Proportion of materials } \\
\text { supplied that did not reach the } \\
\text { school (\%) }\end{array}$ \\
\hline Olive Sch. I, Bodija & 25 & 0 & 100 \\
\hline St. Thomas, Agbowo & 25 & 0 & 100 \\
\hline IMG II, Inalende & 25 & 0 & 100 \\
\hline Methodist I, Bodija & 25 & 0 & 100 \\
\hline St. Paul Sch. III, Yemetu & 25 & 0 & 100 \\
\hline CAC, Oniyanrin & 25 & 0 & 100 \\
\hline St. Mary's, Oke Are & 25 & 0 & 100 \\
\hline Olive Sch. II, Bodija & 80 & 0 & 100 \\
\hline Community Pry, ljokodo & 80 & 0 & 100 \\
\hline Islamic Mission I \& III, Odoye & 160 & 0 & 100 \\
\hline IMG II, Ojelgosun & 80 & 0 & 100 \\
\hline St. John's, Nalende & 80 & 0 & 100 \\
\hline CAC I, Sango & 80 & 0 & 100 \\
\hline Alaafia Institute, Mokola & 80 & 0 & 100 \\
\hline Salvation Army III, Yemetu & 80 & 0 & 100 \\
\hline Ebenezer, Nalende & 80 & 0 & 100 \\
\hline Total & 975 & 0 & \\
\hline
\end{tabular}

Source: Oyo State Universal Basic Education Board, PBEETSQ

The result from Table 5.12 showed that $100 \%$ of the health education textbooks supplied to the schools listed above did not reach them. This showed that none of the 975 textbooks were received by the schools.

\section{DISCUSSION}

\subsection{Evidence of Resource Leakage}

This research indicated that leakage of non-wage education expenditure was in most cases $100 \%$ in Nigeria; $100 \%$ of the ECCDE reading and writing textbooks supplied by SUBEB did not reach the schools (Table 5.1), 100\% of ECCDE mathematics textbooks supplied to the schools did not reach them (Table 5.2), 100\% of the ECCDE nursery living habits textbooks supplied to the schools were not received (Table 5.3), 100\% of the ECCDE nursery physical education textbooks supplied did not reach the schools (Table 5.4), 100\% of the variety toys did not reach the schools (Table 5.5), $100 \%$ of the elementary science textbooks supplied did not reach the schools (Table 5.8 ), $100 \%$ of the social studies textbooks supplied by SUBEB were not received by reach the schools (Table 5.9), 100\% of the basic science and technology textbooks supplied did not reach the schools (Table 5.10), 100\% of the computer textbooks supplied were not received at the school level (Table 5.11) and 100\% of the health education textbooks supplied did not reach the schools (Table 5.12).Leakage of non-wage education expenditures was also confirmed in many countries where PETS had been carried out (Gauthier, 2006; Ablo\&Reinikka, 1998; Reinikka\& Smith, 2004; Reinikka\&Svensson, 2001). The percentage of funds not reaching the schools (average) was given as $49 \%$ in Ghana, 30\% in Peru, $57 \%$ in Tanzania, $87 \%$ in Uganda and $76 \%$ in Zambia. Given that instructional materials is key to improving the quality of schooling, the fact that many of this input never reaches the schools is a major policy concern in the education sector

According to Babalola et al (2007), once the fund has been transformed into instructional materials, they will be passed to the LGUBEA whose duty is to distribute them to the schools. The interview conducted revealed that leakages existed at both SUBEB and LGUBEA. It was gathered that Oyo SUBEB delayed the award of contract and release of funds to contractors after the fund had been accessed. As a result, some of the textbooks became obsolete (due to change in curriculum) even at the press and were no longer useful by the time it got to the schools. Also, there existed a discrepancy in quantity printed and actual delivery to LGUBEA. Between LGUBEA and the schools, the following patterns of leakage were also established: inequalities of distribution, diversions and delays in distribution. The research showed that the schools officially had no knowledge of allocation made to them and as such does not know what was due to them (in Madagascar, only 35\% of the schools reported knowing what they were supposed to receive at the beginning of the year). Oyo SUBEB and LGUBEA took advantage of this lack of knowledge to reduce or stop allocation to some schools, knowing it would attract little attention. In order to control leakage, these identified weak links and bottlenecks in the service supply chain should be made the focus of reforms where the five features of accountability will be promoted. Since UBEC had delegated the provision of UBE to the SUBEB and LGUBEA, backed it up with necessary finance, then it is the responsibility of UBEC to monitor their performance, obtain information about performance from the schools and citizens and enforce discipline when there is non-compliance.

\subsection{Existence of Lobbying}

This research indicated that $100 \%$ of the schools that received instructional materials got more than their allocation. While investigating the reason why some schools suffer more leakage than others, Reinikka and Svensson (2001) found that resource flows and leakage were dependent on school characteristics. Schools with influential Parent Teacher Association 
(PTA) and better informed teachers were the ones that were able to pay the cost of information and lobbying and hence claimed what was due to them. This research revealed in Table 5.6 and Table 5.7 that schools that received Primary English and mathematics textbooks got more than was due to them; $33 \%$ received more than they were supposed to get while $67 \%$ received nothing. While interviewing the HT and AHT of the visited schools, it was gathered that those lucky schools got their materials because of their connection with some politicians and influential parents. Those that did not have the ability to voice their claims received nothing.

\subsection{Importance of information}

Accountability systems often work best when information on financial and resource flows is easily available to all stakeholders in the system. If information on resource allocation by SUBEB had been made available to all stakeholders, each of the schools would have known what to expect and where to lodge complaints if the instructional materials were not received. According to Gauthier (2006), a follow-up PETS was carried out in Uganda to collect data on access to information and capitation grant reception among the PETS 1996 school sample in order to evaluate the impact of the information campaign on leakage levels. It was established that the information campaign accounted for about $3 / 4$ of the improvement in leakage reduction.

There is the need for a policy intervention that will make information readily available to all stakeholders and empower schools to lodge complaints about non-compliance. UBEC should publish the matching grant allocations to the states at the beginning of each year and the un-accessed matching grant update in the newspapers by the middle of the year to create public awareness. Once the citizens get this information, they will make a demand for their rights from SUBEB and their voice will pressurize the states who fail to access their grants to perform. Also, SUBEB should publish the State Action Plan in the newspapers in order to sensitise the citizen and the schools. Once they know what is due to them, they will demand for their entitlements. This will go a long way to reduce leakage of funds at SUBEB and LGUBEA levels.

\subsection{Non-release of instructional materials to students}

The survey also indicated that some schools did not make the textbooks available to the students and that was counterproductive because many of the parents cannot provide textbooks for childrenbecause they are low income earners who live in urban blights/slums and depend on free educationin public schools. Failure on the path of the school to make the books available for students' use will further hamper theirright to education; UBE goal of providing functional, quality and free universal basic education for every Nigerian child of school going agewill be unattainable. Consequently, government investment in education will be a waste since it would not be able to boost productivity, facilitate economic growth, reduce inequality among social groups and contribute to the personal and social development of individuals. If this happens, the nation will not be able to achieve the EFA goals and MDGs or keep up with the pace of technological advancement in the current world.

\section{RECOMMENDATIONS}

PETS has been a powerful instrument for collecting information on the service delivery chain and local service providers in order to appraise the efficiency and equity of government expenditures. This survey has identified the resources available at various levels of the supply chain, examined the behavior of various agents within institutional arrangements, and identified problems of governance, capture of funds and corruption, which is in agreement with other tracking surveys carried out in over fifteen countries over the last eighteen years. In several countries, the survey suggested areas where reforms could be effectively implemented.

This survey in consonance with other survey reports makes the following recommendations:

1. There should be a policy intervention that will make information readily available to all stakeholders. This information campaign should include:

a. Publishing of the matching grant allocations to the states by UBEC at the beginning of each year and the unaccessed matching grant update in the newspapers by the middle of the year to create public awareness. Once the citizens get this information, they will make a demand for their rights from SUBEB and their voice will pressurize the states who fail to access their grants to perform.

b. SUBEB should publish the State Action Plan in the newspapers in order to sensitise the citizen and the schools. Once they know what is due to them, they will demand for their entitlements. Each of the schools would have known what to expect and where to lodge complaints if the allocated resources were not received. This will go a long way to reduce leakage of funds at SUBEB and LGUBEA levels.

2. There should be policy reforms aimed at improving and enforcing public accountability where the five features of accountability will be promoted. Since the Federal Government had delegated the provision of UBE to UBEC, SUBEBs and LGUBEAs, backed it up with necessary finance; then it is the responsibility of UBEC to monitor their performance, obtain information about performance from the schools and citizens, and enforce discipline when there is non-compliance.

3. Improvement of internal controls, in particular accounting and reporting systems in order to enhance transparency and accountability (basic accounting systems are often not in place and rules not followed). This will reduce leakage and curb corruption.

4. Providing additional training for decentralized government levels and service delivery units. 
5. Improving and increasing the quality of inspection and monitoring at all level of the service delivery system. It has been observed that the various monitoring mechanisms are weak and their inspection has been mere routine. Routine Project Monitoring, Specialized Monitoring and Special Financial Audit should be properly carried out by well trained personnel.

\section{Conclusion}

This study has revealed that almost all the resources meant for schools did not reach the school levels in the study area for so many reasons. This appears to be a disturbing revelation that requires prompt government's intervention not only in Oyo State but generally in Nigeria. If the government has the political will to put these recommendations into practice, educational resources will be able flow smoothly and unhindered through the hierarchy, from the government to the schools.

\section{ACKNOWLEDGMENTS}

Our thanks to our enumerators, Tony Adeniji and NnoyeNwakwo, who assisted us to administer the questionnaires in some of the schools.

\section{REFERENCES}

[1] Ablo, E., \&Reinikka, R. (1998). Do budgets really matter? Evidence from public spending on education and health in Uganda. World Bank Policy Research Working Paper 1926, World Bank, Development Research Group, Washington, D.C. Retrieved from:http://www.worldbank.org/html/dec/Publications/Workpapers/WPS1900series/wps1926/wps 1926. pdf

[2] Babalola, J.B., Tukur, H. \&Nzeribe, A. (2007). Effective management of FGN -UBEC intervention fund in selected Nigerian states. A Research Report sponsored by and submitted to Universal Basic Education Commission, Abuja, Nigeria.

[3] Compulsory, Free Universal Basic Education (Act) 2004. Retrieved from: http://www.ilo.org/dyn/natlex/natlex_browse. details?p_lang=en\&p_country=NGA\&p_classification=04\&p_origin=SUBJECT

[4] Das, J., Dercon, S., Habyarimana, J. \& Krishnan, P. (2004). Public and private funding of basic education in Zambia : implications of budgetary allocations for service delivery. Africa Region Human Development working paper series ; no. 62; Africa education country status report. Washington, DC: World Bank. Retrieved from: http://documents.worldbank.org/ curated/en/2004/01/4065892/public-private-funding-basic-education-zambiaimplications-budgetary-allocations-service-delivery

[5] Eya, P.E. (2000). Strategies for successful implementation of UBE in Nigeria. Journal of Multi-disciplinary Studies. Vol.4.No.1.pp 58-62 Brown, L. D., Hua, H., and Gao, C. 2003. A widget framework for augmented interaction in SCAPE.

[6] Gauthier, B. (2010). PETS-QSDS in Sub-Saharan Africa: A Stocktaking Study. Washington, DC: Montreal, HEC. And World Bank. Retrived from:http://documents.worldbank.org/curated/en/2010/07/16505739/pets-qsds-sub-saharanafrica-stocktaking-study

[7] Apoyo, I. and the World Bank (2002)."PETS: The Education Sector in Peru." Background paper for Report to the Public Expenditure Review: Peru, Restoring Fiscal Discipline for Poverty Reduction. Report No. 24286-PE. Washington, D.C. September 25.

[8] Price Waterhouse Coopers (1999). "Tanzania Public Expenditure Review: Health and Education Financial Tracking Study," Two Volumes, commissioned by the Government of Tanzania and DFID, Contract Reference TAN106/4, March 1999, Dar es Salaam.

[9] Reinikka, R. \&Svensson, J. (2001). Explaining Leakage of Public Funds. Policy Research Working Paper 2709. The World Bank, Washington, DC.

[10] Reinikka, R. \& Smith, N. (2004). Public Expenditure Tracking Surveys in Education. International Institute for Educational Planning, UNESCO, Paris.

[11] Reinikka, R. \&Svensson, J. (2004). Local Capture: Evidence from a Central Government Transfer Program in Uganda. Quarterly Journal of Economics, 119 (2): 1-28.

[12] United Nations (1948). Universal Declaration of Human Rights. Retrieved from http://www.un.org/en/documents/udhr/ index. shtml\#a26

[13] United Nations Department of Economic and Social Affairs (DESA, 2009): The Millennium Development Goals Report 2009. New York: United Nations.

[14] World Bank (2004). "World Development Report 2004: Making Services Work for the Poor", World Bank, Washington DC: Co-publication of the World Bank and Oxford University Press.

[15] World Conference on Education for All 1990. The Education for All Goals. The Inter-Agency Commission (UNDO, UNESCO, UNICEF, WORLD BANK). New York. Retrieved from: http://www.unesco.org/education/wef/enconf/Jomtien\%20Declaration\%20eng.shtm 


\section{ISSN 2278-7690}

[16] Ye, Xiao, and SudharshanCanagarajah 2002. "Efficiency of Public Expenditure Distribution and Beyond: A Report on Ghana's 2000 Public Expenditure Tracking Survey in the Sectors of Primary Health and Education." Africa Region Working Paper31, (June). Retrieved from: http://www.worldbank.org/afr/wps/wp31.htm

\section{Author' biography with Photo}

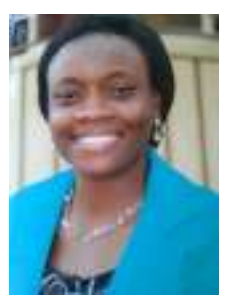

AbisolaGbenro is a researcher and postgraduate student (Economics of Education) in the Department of Educational Management, University of Ibadan, Ibadan, Nigeria. Her ambition is to promote the achievement of goal 2 of the Education for All Goals which is to "Provide free and compulsory primary education for all" in Ibadan in particular and Nigeria in general, so that children everywhere, boys and girls alike, will be able to complete a full course of basic schooling.

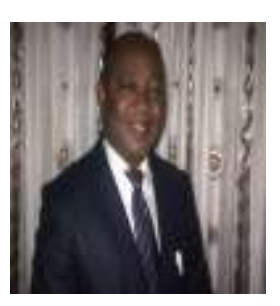

Joel B. Babalola is a Professor of Educational Management (Economics of Education and Strategic Planning) in the Department of Educational Management, University of Ibadan, Ibadan, Nigeria. He has serverd the University of Ibadan as the Head of Department, Sub-Dean of the Faculty of Education and the Dean of the Faculty of Education. He is the writer of "cost and financing of university education in Nigeria"published in Higher Education, Volume 36, Issue 1, pp 43-66 The Netherland; the lead-author with Sikwibele, Anne L (1998) "education as aided by the World Bank in Africa: controversy, dilemma and possible initiatives"; lead-author with Lungwangwa, Geoffrey; Adeyinka, Augustus A "education under structural adjustment in Nigeria and Zambia in McGill Journal of Education Volume 34, No 34 p79-98". 